Клімов С. В., к.т.н., доцент (Національний університет водного господарства та природокористування, м. Рівне)

\title{
ЗМЕНШЕННЯ УЩІЛЬНЕННЯ ҐРУНТУ ПРИ БУДІВНИЦТВІ ГОРИЗОНТАЛЬНОГО ТРУБЧАСТОГО ДРЕНАЖУ БЕЗТРАНШЕЙНИМ СПОСОБОМ
}

В статті наводиться аналіз основних конструктивних рішень зі зменшення ущільнення ґрунту в навколодренній зоні при будівництві горизонтального трубчастого дренажу безтраншейним способом. В огляді наведені приклади як існуючих дреноукладачів з пасивним робочим органом різних країн, так і перспективні розробки в даному напрямку.

Ключові слова: горизонтальний трубчастий дренаж, екскаватордреноукладач, безтраншейний спосіб.

Одним з основних способів регулювання рівня ґрунтових вод на землях сільськогосподарського призначення $€$ горизонтальний трубчастий дренаж. Він застосовується і в зоні з періодичним профіцитом так і з дефіцитом вологи. Будівництво закритих дренажних трубопроводів здійснюється наступними способами: траншейним, вузькотраншейним і безтраншейним. Останній спосіб дозволяє виконувати роботи з більшою продуктивністю праці і меншою вартістю, зокрема за рахунок різкого скорочення обсягів земляних робіт і мінімального виносу мінерального ґрунту на поверхню [1].

При вкладанні дрен безтраншейним способом основною машиною $є$ ножовий дреноукладач зі спареним робочим органом - землерийним і трубоукладальним. Ножовий дреноукладач здійснює прорізання в ґрунті глибокої вузької щілини пасивним землерийним робочим органом з одночасним укладанням на дно щілини пластмасової дренажної труби із синтетичним фільтром чи фільтруючою обсипкою [2].

На сьогодні в Україні в нормативних документах, зокрема в ДСТУ Б. Д.2.2-1-2012 Земляні роботи для вкладання дренажу безтраншейним способом в зоні осушення пропонується дреноукладач МД-4 з тягачем МД-5, який прорізає щілину глибиною до 1,8 м, шириною 0,23 м. Одночасно укладаються пластмасові дренажні труби в ґрунтах I-III категорій при вмісті кам'янистих включень діаметром не 
більш 0,4 м і прихованої деревини діаметром не більш 0,1 м. Технічна продуктивність в ґрунтах 1 категорії складає 1000 м/год, а точність дотримання похилу $\pm 0,0005$ м. Допустима висота (глибина) місцевих нерівностей не повинна перевищувати 0,2 м на довжині 5 м, а поперечний ухил траси не більше $3^{\circ}$, що іноді вимагає формування спланованого «корита» бульдозерами або автогрейдерами. База дреноукладача МД-4 - трактор Т-130.1.Г-1 (117,6 кВт) [2].

За ДСТУ Б. Д.2.2-1-2012 безтраншейний дренаж нормується групою 113 “Влаштування дренажу з пластмасових труб дреноукладачами (безтраншейними) з тягачами потужністю 118 кВт". На вимірник кінцевої продукції 1000 метрів дренажу норми часу для ґрунтів 1,2,3 становить відповідно $\mathrm{H}_{4}=12,95,14,28$ та 15,81, що вказує на продуктивність 77,2, 70,0 та 63,3 м/год.

Однак ножові дреноукладачі поряд з перевагами мають недоліки, до яких можна віднести:

- необхідність застосування базових машин зі значними тяговим зусиллями для подолання значного опору ножа;

- ґрунт у стінках і дні щілини ущільнюється ножем дреноукладача, що приводить до зниження водоприймальної здатності дрен.

Робочий процес ножових дреноукладачів має свої особливості в порівнянні з робочим процесом землерийних машин (бульдозери, скрепери, екскаватори та ін.), що діють за принципом різання ґрунтів з відділенням стружки. Ножові дреноукладачі працюють за принципом розрізання ґрунту, що відрізняється великою енергоємністю [3].

Однією $з$ істотних особливостей робочого процесу ножових дреноукладачів $є$ просторовість взаємодії ножа з ґрунтом, що виявляється в трапецеїдальному поперечному перерізу щілини, утвореної в результаті проходу ножа [4]. Ширина зони руйнування ґрунту на поверхні у багато разів перевищує ширину ножа, отже, робота сил різання витрачається на відділення від масиву і руйнування ґрунту, що знаходиться за межами ширини ножа.

До числа характерних особливостей робочого процесу ножових дреноукладачів відноситься також наявність кількох зон по глибині щілини. Ножовий робочий орган здійснює розрізання ґрунту на велику глибину, що значно (в 5-15 разів) перевищує ширину прорізу, в результаті в грунті по глибині щілини виникають деформації різного характеру. При глибокому різанні ґрунту ножем дреноукладача утворюється дві зони: зона розпушування (верхня) і зона ущільнення (нижня), зона розпушування збільшується до деякої глибини різання, названої критичної, а нижче критичної відбувається ущільнення 
ґрунту ножем в бічні стінки і дно щілини $[4 ; 5]$.

У зоні ущільнення (рис. 1) ґрунт під дією ріжучої кромки ножа піддається постійному пружнопластичному стиску і витісняється в дно і стінки щілини, контактний тиск на лобову грань ножа залишається практично постійним по глибині різання і за абсолютною величиною пропорційний опору ґрунту руйнуванню.

У зоні розпушування, що безпосередньо примикає до денної поверхні, ґрунт стиснутий ріжучою крайкою ножа витісняється від масиву в бік денної поверхні, спостерігається спучування ґрунту поблизу ножового робочого органу з утворенням конуса розпушування, кут нахилу поверхонь зсуву становить в середньому 35-40 від горизонталі. Контактний тиск на лобову крайку ножа знижується зі зменшенням глибини.

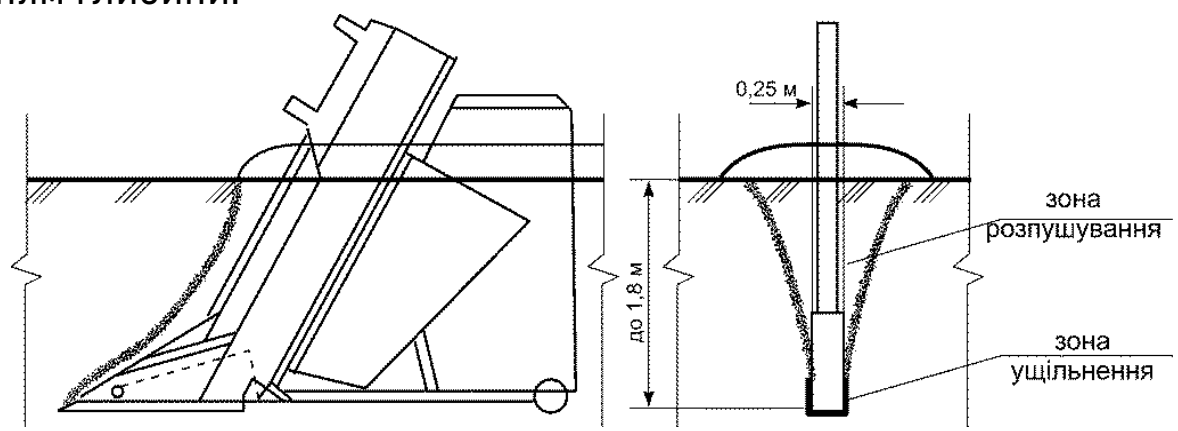

Рис. 1. Зони ущільнення та розпушення ґрунту при роботі безтраншейного дреноукладача з прямим ножем (Straight Leg Plow)

Наявність двох зон при глибокому різанні обумовлено стисканням ґрунтів під дією навантаження. Діюче на ґрунт навантаження призводить до руйнування структурних зв'язків, взаємному зміщенню частинок ґрунту, заповнення пор між ними, а також витіснення води і газової фази. Грунт деформується доти, доки тиск з боку ріжучої кромки ножа не стає достатнім для відділення частини ґрунту від масиву, що є характерним для зони розпушування. У зоні ущільнення тиск з боку ріжучої крайки ножа на ґрунт недостатній для відділення частини ґрунту від масиву і відповідні йому деформації сприяють ущільненню ґрунту [4].

Межею поділу двох зон, як уже зазначалося, є критична глибина. При глибинах менше критичної зусилля різання залежить від глибини за параболічною залежністю, при глибині більше критичної - за прямолінійною залежністю. Величина критичної глибини різання залежить від основних параметрів ножового робочого органу і фі- 
зико-механічних властивостей ґрунтів [3].

Отримане в результаті дії дренажного плуга ущільнення ґрунту зменшує водоприймальну здатність дрени, що доказано практичними дослідженнями як вітчизняних науковців, так і закордонних [6]. Наприклад, KANWAR, RS в роботі [7] наводить дані з проведених в 1980-1984 роках польових досліджень порівняння траншейного та безтраншейного способу вкладання дренажу. Траншейний спосіб показав упродовж всього вегетаційного періоду нижче рівень ґрунтових вод, що підтвердив його кращу ефективність у відведенні води при порівнянні з традиційним безтраншейним способом.

При вкладанні дренажу траншейним способом зона порушення (розпушення) ґрунту має ширину 30-40 см, а при безтраншейному традиційному способі ця зона становить лише 7-17 см (CHOW, TL, [8]). Об'ємна щільність мінерального грунту в траншеї також суттєво менше ніж в природному стані, і менше ніж при розпушенні безтраншейним способом. Відсоткове зниження об'ємної щільності суттєво не змінилось упродовж тривалого періоду часу (до 30-40 років, [8]). Вказана зміна об'ємної щільності призводить до підвищення насиченої гідравлічної провідності розпушених ґрунтів, а відповідно і кращій роботі дренажу.

Існує декілька напрямків розвитку ножових робочих органів. По-перше це передача частини потужності двигуна безпосередньо на робочий орган, минаючи колеса або гусениці. В даний час даний напрямок має важливе значення завдяки існуючій тенденції збільшення потужності двигунів, які застосовуються на безтраншейних дреноукладачах. Підведення частини енергії двигуна до робочого органу може бути здійснено наступними способами: застосуванням вібрації, гідродинамічним і газодинамічних впливом, застосуванням додаткових механічних засобів (фрези та ін.), що встановлюються на ножі і комбінованим способом. Вібруючі робочі органи можуть здійснювати вертикальні, поздовжні, еліптичні і кругові коливання, можуть бути створені ножі з примусовою вібрацією їх окремих частин. При розробці ножових робочих органів для руйнування ґрунту газодинамічних впливом з подачею на поверхню робочого органу стиснутого повітря, що сприяє зниженню тертя між поверхнею ножа і ґрунтом, потік стисненого повітря може бути пульсуючим або безперервним. 
Другий напрямок зниження питомого опору на пасивні ножі дреноукладачів $€$ покриття поверхонь робочих органів ножових дреноукладачів антифрикційними матеріалами, що знижують тертя в зонах взаємодії робочого органу з ґрунтом. Проводились дослідження нових методів зниження опору при руйнуванні вологих ґрунтів шляхом застосуванням електросмоса, електромагнітного, електрогідравлічного і термічного способу [3]. Однак дані способи не усували такий недолік ножових дреноукладачів, як ущільнення ґрунту в стінки щілини і навколо дрени, що суттєво зменшує водоприймальну здатність дрен.

Вказаний недолік можливо усунути впровадженням розроблених в НУВГП багатоярусних робочих органів дреноукладачів, які суттєво зменшують ущільнення ґрунту в стінки щілини, що збільшує інтенсивність надходження води в дренажні труби, а відповідно і збільшує ефективність дії дренажу з відведення надлишкової ґрунтової води.

Робочий орган укладача-розпушувача [9] включає похило встановлений трубонапрямний тракт та закріплені на ньому з рознесенням по висоті з випередженням кожного наступного в напрямку від нижнього до верхнього ґрунторозробні органи, кожний з яких виконаний з вертикального розрізного ножа і дотичних з ним горизонтальних ножів, лобові поверхні яких спряжені з робочими поверхнями транспортувально-напрямних елементів. Згідно з винаходом, кожний транспортувально-напрямний елемент являє собою жолоб. Це дозволяє працювати в режимі докритичного різання і уникати ущільнення стінок щілини. Однак нажаль дані технічні рішення не знайшли застосування в серійних машинах.

Останні роки в Україні почала дуже широко використовуватись будівельна техніка іноземних фірм - одноківшеві екскаватори, бульдозери та ін. Тому доречним є розглядати можливість придбання і використання сучасної техніки провідних іноземних фірм і для будівництва закритого матеріального дренажу безтраншейним способом, тому розглянемо основні з них [2].

RWF Industries (Канада) - займається розробкою, виробництвом і продажем важкої техніки з 1974 року. Даною фірмою виготовляються та продаються в багатьох країнах світу під маркою BRON як самохідні дренажні плуги (Self-Propelled Drainage Plow) 2-х видів, 
так і начіпні дреноукладачі дреноукладачі.

Inter-Drain - фірма виготовляє дреноукладачі з активними і пасивними робочим органами. Безтраншейні дреноукладачі базуються на трьох різних принципах начіпки робочого органу: Double-linkage system, GP-Series; Single-linkage system, TL-Series; Single beam system, SP-Series.

Фірма Mastenbroek Ltd (Великобританія) випускає широкий спектр машин для будівництва дренажу. Машини для безтраншейного вкладання дренажу (Drainage Plow) даної фірми можуть бути 3 одним прямим ножем-стійкою (Straight Leg Plow) та 3 ножем V-подібної конструкції (V-Plow) (рис. 2). Ніж V-Plow дозволяє уникнути суттєвого недоліку ножів традиційної конструкції - ущільнення ґрунту, він навпаки розпушує ґрунт над дреною, що покращує приток води до дрени (рис. 2, а). Це досягається також спеціальною формою загострення лез ножа - в бік зони розпушення (рис. 2, б).

Дренажний плуг (Trenchless Drainage Plow) V-plow дозволяє отримати гарні показники ґрунту в навколодренній зоні в різних ґрунтах. Зокрема в Єгипті побудовані 141 км дренажних ліній бічної мережі в напівнестійких, середньо- і дрібно-структурованих ґрунтах (semi-unstable, in medium textured and fine textured soils) показали кращі показники ніж стандартні дренажні плуги та траншейні екскаватори-дреноукладачі [10].

V-plow може вкладати максимальний діаметр зовнішньої труби, включаючи захисно-фільтруючий матеріал, від 0,10 до 0,125 м (Cavelaars et al., [11]). При цьому вертикальний ніж може вкладати значно більші діаметри. Це зокрема пов'язано з більшою кількістю змін напрямку труби в трубопровідному тракті.

Досвід Західної Європи та Північної Америки вказує на меншу вартість безтраншейного способу вкладання при глибинах дренажу до 1,3-1,4 м, що пояснюється значно більшою швидкістю вкладання. В Нідерландах при глибинах дренажу від 1,0 до 1,2 м та діаметрами труб до 0,08 м, різниця складає від 15 до 25\% [1]. Однак перевага безтраншейного вкладання швидко зменшується при збільшенні глибини вкладання дренажу та збільшенням опору різання ґрунту (рис. 3). 

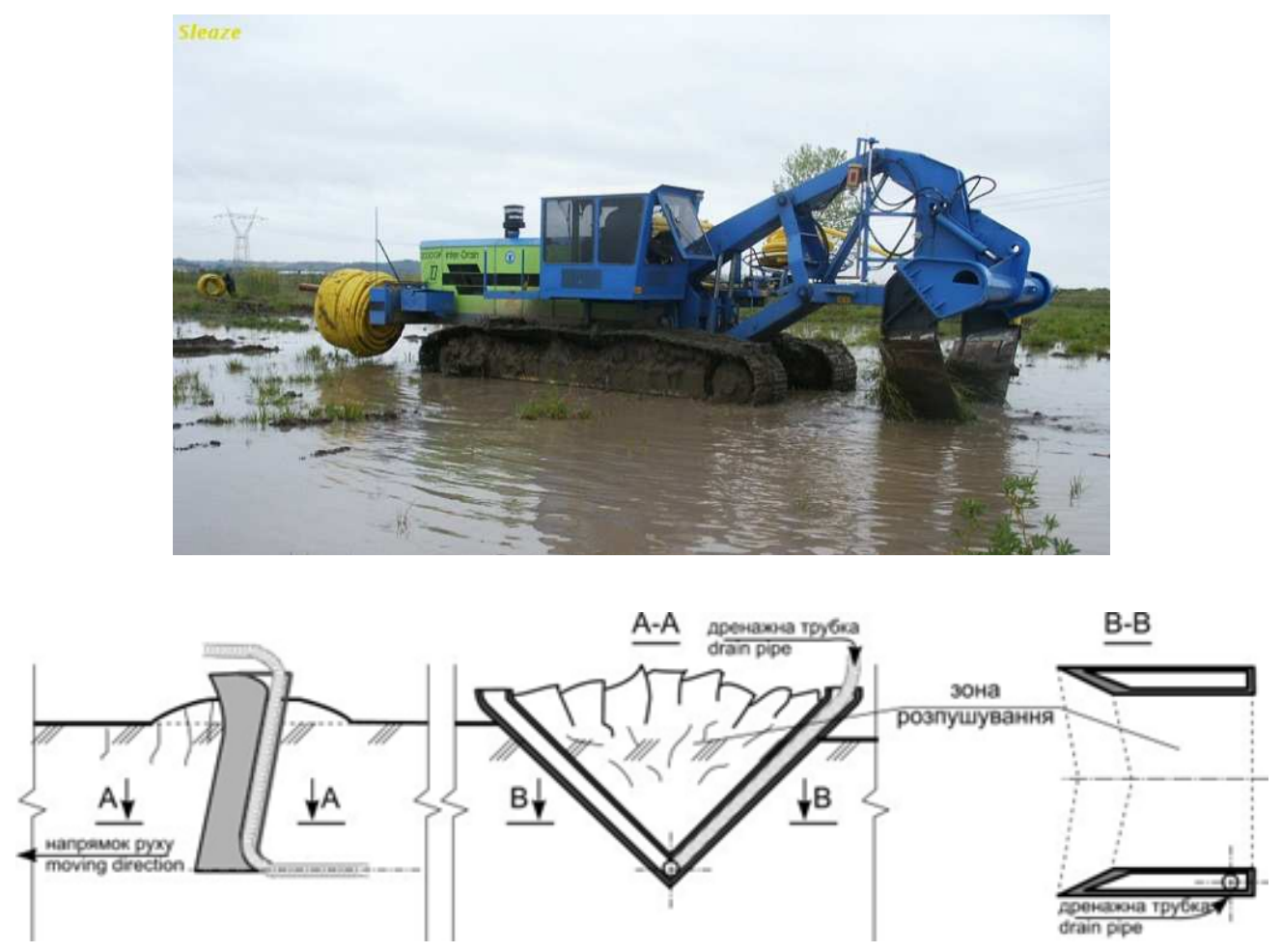

Рис. 2. Ніж V-подібної конструкції (V-Plow): а) на дреноукладачі фірми Mastenbroek; б) схема різання ґрунту, види ззаду та збоку

Таблиця 1

Приклад залежності продуктивності при вкладанні дренажу від глибини вкладання та способу вкладання для траншейного способу (160 кВT) та безтраншейного способу вкладання V-подібним плугом (200 кВт) для встановлення дренажу в Нідерландах (джерело: Van Zeijts and Naarding, [12])

\begin{tabular}{|c|c|c|c|c|c|}
\hline \multirow[b]{2}{*}{$\begin{array}{l}\text { № } \\
3 / \Pi\end{array}$} & \multirow[b]{2}{*}{$\begin{array}{c}\text { Тип } \\
\text { ґрунту }\end{array}$} & \multirow{2}{*}{$\begin{array}{l}\text { Глибина } \\
\text { вкладан- } \\
\text { ня дрени } \\
\text { (м) }\end{array}$} & \multicolumn{2}{|c|}{ Продуктивність, м/год } & \multirow{2}{*}{$\begin{array}{c}\text { Коефіцієнт } \\
\text { безтраншей- } \\
\text { ний / тран- } \\
\text { шейний }\end{array}$} \\
\hline & & & $\begin{array}{c}\text { Траншей- } \\
\text { ним }\end{array}$ & Безтраншейним & \\
\hline 1 & \multirow{4}{*}{ Пісок } & 1,0 & 700 & 840 & 1,2 \\
\hline 2 & & 1,3 & 600 & 600 & 1,0 \\
\hline 3 & & 1,6 & 520 & 430 & 0,8 \\
\hline 4 & & 1,9 & 475 & - & - \\
\hline 5 & \multirow{4}{*}{$\begin{array}{c}\text { Важкий } \\
\text { суглинок i } \\
\text { глина }\end{array}$} & 1,0 & 620 & 1150 & 1,9 \\
\hline 6 & & 1,3 & 540 & 1050 & 1,9 \\
\hline 7 & & 1,6 & 470 & 800 & 1,7 \\
\hline 8 & & 1,9 & 420 & - & \\
\hline
\end{tabular}




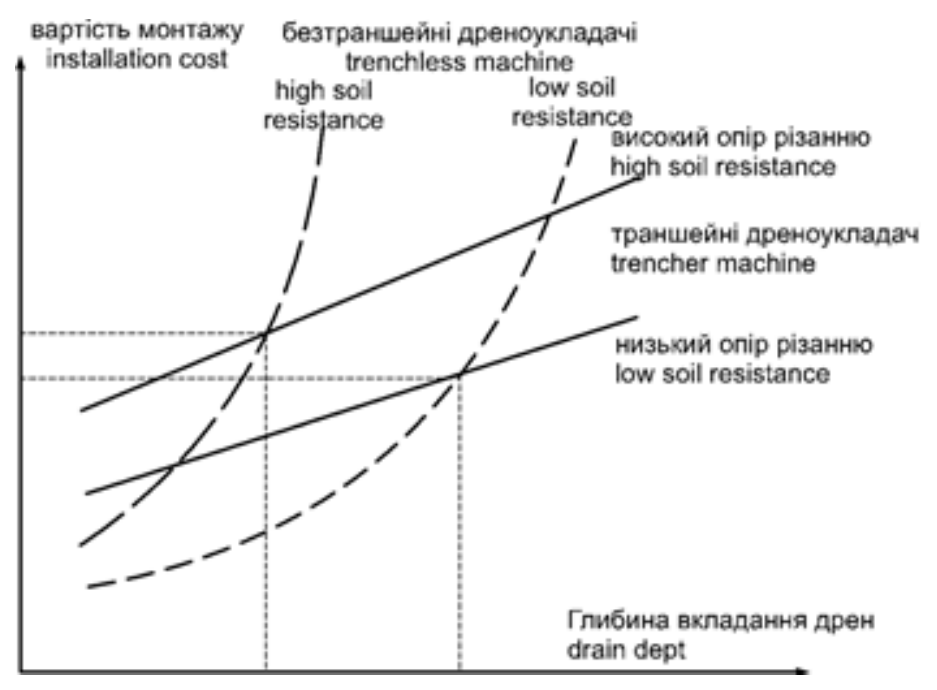

Рис. 3. Порівняння питомої вартості вкладання дренажу від глибини дрен траншейним способом та дреноукладачем V-подібної конструкції [12]

3 наведеного матеріалу видно, що:

- Безтраншейний спосіб вкладання дренажу $є$ перспективним при будівництві дренажних систем, особливо з врахуванням його значної переваги перед траншейним способом за продуктивністю та трудовитратами.

- Робочі органи дреноукладачів з одним прямим ножем-стійкою (Straight Leg Plow) на глибинах більше критичної призводять до ущільнення ґрунту в стінки та дно щілини, що створює додатковий опір надходженню води в дрени і зменшує їх водоприймальну здатність $[4 ; 5]$.

- Існує декілька варіантів запобіганню зменшення водопровідності придренних шарів, як на рівні винаходів та авторських свідоцтв [3], так і машини, що вже серійно випускаються відомими виробниками.

- Конструкція дреноукладача Mastenbroek з ножем V-подібної конструкції (V-Plow) дозволяє уникати ущільнення ґрунту і створює сприятливі умови для надходження води в дрени [10].

Доцільність застосування дреноукладача Mastenbroek V-Plow в конкретних ґрунтових умовах і заданої глибини вкладання дренажу, порівняно з траншейним способом, можна визначати за відомим графіком (Van Zeijts and Naarding, [12]).

1. Nijland, H. J., F. W. Croon and H. P. Ritzema, 2005. Subsurface Drainage Practices: Guidelines for the implementation, operation and maintenance of subsurface pipe drainage systems. Wageningen, Alterra, ILRI Publication no. 60, pp. 608. 2. Клімов С. В. Сучасні технології будівництва горизонтального 
трубчастого дренажу безтраншейним способом. Вісник Національного університету водного господарства та природокористування. Технічні науки. Рівне : НУВГП, 2011. Вип. 2(54). С. 56-64. 3. Аль-Дмур Б. А. С. Совершенствование рабочего процесса ножевых дреноукладчиков применением сжатого воздуха / Аль-Дмур, Бассам Абдалла Сальман / дисерт. к.т.н., 05.05.04. 1984. URL: http://www.dissercat.com/content/sovershenstvovanierabochego-protsessa-nozhevykh-drenoukladchikov-primeneniem-szhatogovozdu (дата звернення: 26.01.2018). 1984. 4. Зеленин А. Н. Физические основы теории резания грунтов. М. Л., АН СССР, 1950. 354 с. 5. Ветров Ю. А. Резание грунтов землеройными машинами. М., «Машиностроение», 1971. 357 c. 6. Spoor G. Field Performance of Trenchless Drainage Tines and Implications for Drainage System Efficiency / G. Spoor, R. Fry // Journal of Agricultural Engineering Research. 1983. Том 28, Вип. 4. С. 319-335. 7. Kanwar R. Comparison of Trenchless Drain Plow and Trench Methods of Drainage Installation / R. Kanwar, T. Colvin, S. Melvin // Transactions of the Asae. 1986. Том 29, Вип. 2. С. 456-461. 8. Chow T. Modification of Subsoil Characteristics Resulting from Drainage Tile Installation / T. Chow, H. Rees, K. Webb, D. Langille // Soil Science. 1993. Том 156, Вип. 5. C. 346-357. 9. Пат. UA 76118 МПК: E02F 5/10. Робочий орган укладача-розпушувача / Ткачук І. В., Кравець С. В., Степанюк А. А., Ткачук В. Ф., Рижий О. П., Хижнюк О. В., Лук'янчук О. П., Романовський О. Л. Опубл. 17.07.2006. 10. Nesralla M. R. Trenchless drainage construction (V-plow) under irrigated conditions, Egypt. I M. R. Nesralla, W. F. Vlotman. St Joseph : Amer Soc Agr Engineers, 1998. 11. Cavelaars, J. C., Vlotman, W. F. and Spoor, G. (1994). Subsurface Drainage Systems. In: H.P. Ritzema (Editor-in-Chief), Drainage Principles and Applications, ILRI Publication 16, International Institute for Land Reclamation and Improvement (ILRI), Wageningen, The Netherlands, pp. 827-929. 12. Van Zeijts, T.E.J. and Naarding, W.H. (1990). Possibilities and Limitations of Trenchless Pipe Drain Installation in Irrigated Areas. In: Installation of pipe drains, Government Service for Land and Water Use, Information Paper 21, Utrecht, pp. 10-22.

\section{REFERENCES :}

1. Nijland, H. J., F. W. Croon and H. P. Ritzema, 2005. Subsurface Drainage Practices: Guidelines for the implementation, operation and maintenance of subsurface pipe drainage systems. Wageningen, Alterra, ILRI Publication no. 60, pp. 608. 2. Klimov S. V. Suchasni tekhnolohii budivnytstva horyzontalnoho trubchastoho drenazhu beztransheinym sposobom. Visnyk Natsionalnoho universytetu vodnoho hospodarstva ta pryrodokorystuvannia. Tekhnichni nauky. Rivne : NUVHP, 2011. Vyp. 2(54). C. 56-64. 3. Al-Dmur B. A. S. Sovershenstvovanye rabocheho protsessa nozhevыkh drenoukladchykov prymenenyem szhatoho vozdukha / Al-Dmur, Bassam Abdalla Salman / dysert. k.t.n., 05.05.04. $1984 . \quad$ URL: http://www.dissercat.com/content/sovershenstvovanie-rabochego-protsessanozhevykh-drenoukladchikov-primeneniem-szhatogo-vozdu (data zvernennia: 26.01.2018). 1984. 4. Zelenyn A. N. Fyzycheskye osnovb teoryy rezanyia 
hruntov. M. L., AN SSSR, 1950. 354 s. 5. Vetrov Yu. A. Rezanye hruntov zemleroinumy mashynamy. M., «Mashynostroenye», 1971. 357 s. 6. Spoor G. Field Performance of Trenchless Drainage Tines and Implications for Drainage System Efficiency / G. Spoor, R. Fry // Journal of Agricultural Engineering Research. 1983. Tom 28, Vyp. 4. C. 319-335. 7. Kanwar R. Comparison of Trenchless Drain Plow and Trench Methods of Drainage Installation / R. Kanwar, T. Colvin, S. Melvin // Transactions of the Asae. 1986. Tom 29, Vyp. 2. C. 456-461. 8. Chow T. Modification of Subsoil Characteristics Resulting from Drainage Tile Installation / T. Chow, H. Rees, K. Webb, D. Langille // Soil Science. 1993. Tom 156, Vyp. 5. C. 346-357. 9. Pat. UA 76118 MPK: E02F 5/10. Robochyi orhan ukladacha-rozpushuvacha / Tkachuk I. V., Kravets S. V., Stepaniuk A. A., Tkachuk V. F., Ryzhyi O. P., Khyzhniuk O. V., Lukianchuk O. P., Romanovskyi O. L. Opubl. 17.07.2006. 10. Nesralla M. R. Trenchless drainage construction (V-plow) under irrigated conditions, Egypt. / M. R. Nesralla, W. F. Vlotman. St Joseph : Amer Soc Agr Engineers, 1998. 11. Cavelaars, J. C., Vlotman, W. F. and Spoor, G. (1994). Subsurface Drainage Systems. In: H.P. Ritzema (Editor-in-Chief), Drainage Principles and Applications, ILRI Publication 16, International Institute for Land Reclamation and Improvement (ILRI), Wageningen, The Netherlands, pp. 827-929. 12. Van Zeijts, T.E.J. and Naarding, W.H. (1990). Possibilities and Limitations of Trenchless Pipe Drain Installation in Irrigated Areas. In: Installation of pipe drains, Government Service for Land and Water Use, Information Paper 21, Utrecht, pp. 10-22.

Рецензент: д.Т.Н., професор Хлапук М. М. (НУВГП)

Klimov S. V., Candidate of Engineering (Ph.D.), Associate Professor (National University of Water and Environmental Engineering, Rivne)

\section{PREVENTION OF SOIL COMPACTION IN THE CONSTRUCTION OF HORIZONTAL TUBULAR DRAINAGE BY THE TRENCHLESS METHOD}

In the article the analysis of the main constructive solutions for reducing the compaction of soil in the near-drain zone at the construction of horizontal drainage from pipes by drainage plows is given. The trenchless installation is promising in the construction of drainage systems, especially taking into account its significant advantage over the trench-type way of productivity and labor costs. The experience of Europe, Africa, Asia, and America indicates a lower cost using drainage plows with a construction drainage depth of 1.3 to 1.4 meters, which is explained by a much higher rate of insertion. In the Netherlands, at depths of drainage from 1.0 to $1.2 \mathrm{~m}$ and diameters of pipes to $0.08 \mathrm{~m}$, the difference is from 15 to $25 \%$. However, the advantage of this method of insertion decreases rapidly with increasing depth of insertion of drainage and increase of the 
resistance of cutting of soil.

However Drainage Straight Leg Plow at more crytical depths will result in soil compaction in the walls and bottom of the crack, which reduces soil watertightness in these zone and adds additional resistance to inflow water in the drains. The review gives examples of both existing drainage-plows of different countries and promising developments in this direction. It was shown that the Mastenbroek VPlow drainage guide avoids soil compaction and creates favorable conditions for inflow water in drains. This is due to the loosening of the soil above the drain, increasing its volume with the bulging on the day surface and the absence of soil compaction zones by redirecting compression forces from the horizontal to the vertical plane.

The V-plow can insert pipes with a maximum external diameter, including protective-filtering material, from 0.10 to 0.125 meters. The V-plow in different soils (semi-unstable, in medium textured and fine textured soils) allows you to obtain better indicators than the usual drainage plows and drainage trenchers. However the advantage of trenchless installation decreases rapidly with greater drain depth and with higher soil resistance. It works best in clay loam and clay, worse in sand.

Keywords: horizontal tubular drainage, drainage plow, V-Plow, trenchless installation.

Климов С. В., к.т.н., доцент (Национальный университет водного хозяйства и природопользования, г. Ровно)

УМЕНЬШЕНИЕ УПЛОТНЕНИЯ ГРУНТА ПРИ СТРОИТЕЛЬСТВЕ ГОРИЗОНТАЛЬНОГО ТРУБЧАТОГО ДРЕНАЖА БЕСТРАНШЕЙНЫМ СПОСОБОМ

В статье приводится анализ основных конструктивных решений по уменьшению уплотнения почвы в околодренной зоне при строительстве горизонтального трубчатого дренажа бестраншейным способом. В обзоре приведены примеры как существующих дреноукладчиков с пассивным рабочим органом резных стран, так и перспективные разработки в данном направлении.

Ключевые слова: горизонтальный трубчатый дренаж, экскаватордреноукладчик, бестраншейный способ. 